\title{
Two new species of Bimastos (Oligochaeta, Lumbricidae) from the Southern Appalachian Mountains, North America
}

\author{
ROBERTO CARRERA-MARTÍNEZ ${ }^{*}$, DANIEL JONES ${ }^{2}$, SEAN D. SCHOVILLE ${ }^{3}$, BRUCE A. SNYDER ${ }^{2} \&$ \\ MAC A. CALLAHAM, JR. ${ }^{4}$ \\ ${ }^{1}$ Department of Integrative Biology, University of Wisconsin-Madison, Madison, WI, USA. \\ ${ }^{2}$ Department of Biological and Environmental Sciences, Georgia College and State University, Milledgeville, GA, USA. \\ ”-djones9513@gmail.com; • https://orcid.org/0000-0002-7338-2519

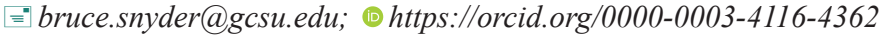 \\ ${ }^{3}$ Department of Entomology, University of Wisconsin-Madison, Madison, WI, USA

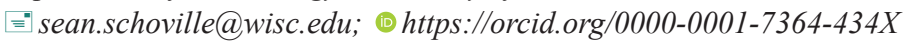 \\ ${ }^{4}$ Southern Research Station, US Forest Service, Athens, GA, USA \\ इ"mac.a.callaham@usda.gov; 은tps://orcid.org/0000-0001-7915-427X \\ "Corresponding Author: |" rcarrmart@gmail.com; @ https://orcid.org/0000-0002-4945-1887
}

\begin{abstract}
Two new species of Bimastos Moore are described based on morphological and molecular data. Bimastos nanae n. sp. resembles B. lawrenceae Fender, B. zeteki (Smith and Gittins) and B. welchi (Smith). Bimastos nanae n. sp. differs from these species in the position of the clitellum, size and number and position of thickened septa. Bimastos magnum n. sp. is similar to B. schwerti Csuzdi \& Chang and B. palustris Moore in having a fully annular clitellum and male pores on huge porophores. Bimastos magnum n. sp. differs from both species by having a more posterior position of the clitellum (in xxiv-xxxiii, xxxiv) and larger body size. With the description of these new species, the number of Bimastos species is raised to 14 .
\end{abstract}

Key words: Earthworm, North American native species, Fire regime, Male pores, Bimastos

\section{Resumen}

Se describen dos especies nuevas de Bimastos Moore en base de datos morfológicos y moleculares. Bimastos nanae n. sp. se asemeja a B. lawrenceae Fender, B. zeteki (Smith \& Gittins) y B. welchi (Smith). Bimastos nanae n. sp. se diferencia de estas especies en la posición de su clitelo, tamaño y localización de los tabiques engrosados. Bimastos magnum n. sp. se asemeja a $B$. schwerti Csuzdi \& Chang y a B. palustris Moore al tener un clitelo completamente anular y sus poros masculinos en poróforos agrandados. Bimastos magnum n. sp. se diferencia de ambas especies al tener clitelo localizado posteriormente (en xxvi-xxxiii, xxxiv) y en tener un tamaño mayor. Con las descripciones de estas dos nuevas especies, el número de especies reconocidas de Bimastos incrementa a 14.

Palabras Clave: Lombrices de tierra, Especies nativas de Norte América, Régimen de fuego, Poros masculinos, Bimastos

\section{Introduction}

Bimastos Moore, 1893 consists of twelve valid species, with most of its diversity concentrated in the midwestern and eastern United States. However, some species have become cosmopolitan throughout the world (Csuzdi et al. 2017). This has made classification and definition of Bimastos historically problematic, with the genus sometimes relegated to subgenus status within Allolobophora or Helodrilus (Michaelsen 1899, 1900; Smith 1917), or having its species placed variously in the genera Eisenia, Dendrobaena, Allolobophoridella and Dendrodrilus (Mršić 1990, 1991; Omodeo 1956; Pop 1941; Zicsi 1981). Bimastos differs from Eisenia and Dendrobaena in having U-shaped nephridial bladders, while Allolobophoridella and Dendodrilus have been synonymized with Bimastos (Csuzdi et al. 2017). 
Bimastos is characterized by having considerable reduction to loss of sexual organs like the spermathecae and the tubercula pubertatis. Reductions of these structures have evolved independently in the genera Healyella Omodeo and Rota, 1989, and Spermophorodrilus Bouché, 1975 (Csuzdi et al. 2017). However, Bimastos is closest to Eisenoides Gates, 1969, forming a single clade containing all North American endemic lumbricids (Domínguez et al. 2015; Csuzdi et al. 2017). Because of the reduction of sexual organs characteristic of the genus and ambiguous descriptions of some species, the number of accepted species of Bimastos has varied between authors over time. A systematic revision by Csuzdi et al. (2017) revealed that the genus contains 12 described species and provided redefinitions of most species based on type series materials. Recent collections in the Appalachian Mountains in North America revealed two undescribed species.

The Appalachian Mountain chain is considered a biodiversity hotspot (Luna-Vega \& Contreras-Medina 2010; Milanovich et al. 2010; Tripp et al. 2019). This region currently has reported over 25 native species of earthworms (Reynolds 2017a; b), including at least seven known Bimastos species. This region has a long history of fire suppression, which allowed the accumulation of leaf litter that ignited in 2016 as a result of human agency and extremely dry condition (Carpenter et al. 2021). Therefore, understanding the diversity of this region is important to promote its conservation, especially given that environmental disturbance events are expected to increase in frequency in the near future (Jolly et al. 2015). During 2017 and 2018, efforts to understand the effects of these two large wildfires in northern Georgia, USA, on soil invertebrates revealed the presence of two undescribed Bimastos species. Both species are herein described using morphological and molecular data.

\section{Methods}

The specimens were killed with $70-95 \%$ ethanol. Then we took body wall tissues samples (ca. $1 \mathrm{~mm}^{2}$ ) for future DNA extraction before the specimens were fixed in $10 \%$ formalin for at least $24 \mathrm{hrs}$. The specimens were examined externally and internally by dorsal dissection, using the taxonomy presented by Csuzdi et al. (2017). Species length, width, and number of segments are presented in a range from all the type material studied. All specimens were deposited in the Georgia Museum of Natural History's Grace Thomas Invertebrate Collection (GTIC).

We extracted the DNA using the Qiagen ${ }^{\mathrm{TM}}$ DNeasy ${ }^{\circledR}$ Blood \& Tissue DNA extraction kit and quantified DNA concentrations using NanoDrop (NanoDrop, Thermo Fisher Scientific Inc.). We amplified the ribosomal 16S gene using the primers 16S-tRNA-Leu-Ala-Ser-Leu-LumbF2 [5 '-CGA CTG TTT AAC AAA AAC ATT GC-3', PérezLosada et al. (2009)], and Ho_16SRa [5'-GCA CTA TTC TGC CAY CTT GT-3', Novo et al. (2010)], and the mitochondrial Cytochrome c Oxidase subunit I (COI) barcode gene using the primers LCO1490 (5'-GGT CAA CAA ATC ATA AAG ATA TTG G-3') and HCO2198 (5'-TAA ACT TCA GGG TGA CCA AAA AAT CA-3'), following Folmer et al. (1994). We performed PCR reactions at $25 \mu \mathrm{L}$ final volume of $12.5 \mu \mathrm{L}$ of GoTaq ${ }^{\circledR}$ Colorless Master Mix (Promega; composed by $2 \mathrm{X}$ Colorless GoTaq ${ }^{\circledR}$ Reaction Buffer of $\mathrm{pH} 8.5,400 \mu \mathrm{M}$ dATP, 400 $\mu \mathrm{M}$ dGTP, $400 \mu \mathrm{M}$ dCTP, $400 \mu \mathrm{M}$ dTTP and $3 \mathrm{mM} \mathrm{MgCl}_{2}$ ), $1.0 \mu \mathrm{L}$ of BSA (1x), and $1.0 \mu \mathrm{L}$ of each of forward and reverse primers $(10 \mu \mathrm{M})$ and of template DNA. An additional $1.0-2.5 \mu \mathrm{L}$ of $\mathrm{MgCl}_{2}(25 \mathrm{mM})$ was added to the $16 \mathrm{~S}$ reactions. The PCR cycling conditions differed for both markers, and we optimized them with the following steps: for COI; PCR cycling conditions were one cycle at $95^{\circ} \mathrm{C}$ for $2 \mathrm{~min}, 40$ cycles at $95^{\circ} \mathrm{C}$ for 30 seconds, $50^{\circ} \mathrm{C}$ for 30 sec, and $72^{\circ} \mathrm{C}$ for $30 \mathrm{sec}$, with a final extension at $72^{\circ} \mathrm{C}$ for $7 \mathrm{~min}$., for $16 \mathrm{~S}$ : PCR cycling conditions were one cycle at $95^{\circ} \mathrm{C}$ for $2 \mathrm{~min}, 35-40$ cycles at $95^{\circ} \mathrm{C}$ for $90 \mathrm{sec}, 60^{\circ} \mathrm{C}$ for $1 \mathrm{~min}$, and $72^{\circ} \mathrm{C}$ for $90 \mathrm{sec}$, with a final extension at $72^{\circ}$ $\mathrm{C}$ for $7 \mathrm{~min}$. We ran PCR products through a 1.3\% agarose gel electrophoresis to confirm successful amplification before cleaning-up the PCR products.

The PCR products were cleaned with $1.5 \mu \mathrm{L}$ of Exo-Sap-IT (Affymetrix) (1:5 dilution with PCR-grade water) and incubated at $37^{\circ} \mathrm{C}$ for $30 \mathrm{~min}$ followed by $80^{\circ} \mathrm{C}$ for $15 \mathrm{~min}$. Then, the Exo-Sap IT cleaned samples were prepared for cycle sequencing in both primer directions, by adding $2.0 \mu \mathrm{L}$ of the DNA to a mix of $0.5 \mu \mathrm{L}$ BigDye 3.1 (Applied Biosystems), $0.5 \mu \mathrm{L}$ of $5 \mathrm{x}$ Sequencing Buffer (Applied Biosystems), $0.33 \mu \mathrm{L}$ of $10 \mu \mathrm{M}$ Primer (of one direction only), and $7.5 \mu \mathrm{L} \mathrm{ddH_{2 }} \mathrm{O}$, for a total volume of $10.83 \mu \mathrm{L}$. The samples were then run through the cycle sequence with an initial denaturation at $95^{\circ} \mathrm{C}$ for 2 min, followed by 25 cycles consisting of denaturation at $95^{\circ} \mathrm{C}$ for $15 \mathrm{sec}$, annealing at $50^{\circ} \mathrm{C}$ for $15 \mathrm{sec}$ and extension at $60^{\circ} \mathrm{C}$ for $4 \mathrm{~min}$ The samples were then prepared on a plate and prepared to be sent for sequencing to the Center of Biotechnology of the University of Wisconsin-Madison, using ABI 3730xl Capillarity Sequencer (https://biotech.wisc.edu/). 
Sequences were aligned using M-Coffee (Wallace et al. 2006), to examine alternative alignment algorithms and finding the best approach. M-Coffee combines eight commonly used alignment algorithms to identify the preferred alignment approach and provides information on the final alignment quality by calculating a score for each individual sequence with respect of the other sequences and the overall alignment quality (Wallace et al. 2006). Both alignments had an overall score of 99 and 96 for COI and 16S, respectively, with individual sequences scoring $\geq 96$ on COI, and $\geq 93$ on 16S. Sequences were trimmed using trimAl (Capella-Gutiérrez et al. 2009) using 5 bp windows, maintaining a minimum of $40 \%$ similarity at each base position, and allowing gaps. Trimming resulted in a sequence length of 648 bp for COI and 489 bp for 16S. Genetic divergence was calculated using Kimura 2-Parameter model (Kimura 1980) with complete deletion on MEGA X (Kumar et al. 2018) using the Bimastos sequences available on GenBank, generated by Csuzdi et al. (2017) and Domínguez et al. (2015). Additional specimens deposited in the GTIC of B. zeteki (GTIC-10325 and 10326), B. longicinctus (GTIC-10684) and B. tumidus (GTIC-11346 to 11348) were studied. Sequences for the B. zeteki and B. longicintus specimens were generated by Ikeda et al. (2020) and downloaded from GenBank.

For the phylogenetic analysis, we included sequences of Eisenoides caroliniensis, and E. lonnbergi as putative sister taxa of Bimastos. For a more distant outgroups, we used Haelyella jordanis, H. syriaca, Fitzingeria platyura platyura, Spermaphorodrilus antiguus, and Dendrobaena alpina with sequences generated by Csuzdi et al. (2017) and Domínguez et al. (2015). The newly and previously generated sequence accession numbers are available in Appendix 1. We concatenated the COI and 16S sequences with MEGA X (Kumar et al. 2018) for a total length of $1137 \mathrm{bp}$. We used ModelFinder (Kalyaanamoorthy et al. 2017) in IQ-TREE ver. 1.6.12 (Nguyen et al. 2015) to determine the most appropiate substitution model based on the corrected Akaike Information Criterion (cAIC). The best substitution model was $\mathrm{GTR}+\mathrm{F}+\mathrm{I}+\mathrm{G} 4$ for $\mathrm{COI}$ and $\mathrm{TIM} 2+\mathrm{F}+\mathrm{I}+\mathrm{G} 4$ for $16 \mathrm{~S}$, and we used RAxML-NG ver. 1.0.2 (Kozlov et al. 2019) to generate the phylogeneic tree implementing this preferred suibstituion model. Branch support was provided by the Transfer Bootstrap Expectation (TBE), as it is performs better on deep branches, and rarely supports weak branches compared to the traditional Felsenstein Bootstrap Proportions (FBP) (Lemoine et al. 2018). A final tree image was generated using ggtree ver. 3.0.2 (Yu et al. 2017) in R ver. 4.1.0 (R Core Team 2021).

\section{Results}

Both new species are supported by a divergence (presented as the proportions of base pair differences) of $0.127-$ 0.185 at the COI locus (Table 1), and of $0.054-0.138$ in 16S sequences (Table 2). Within species distances for Bimastos magnum and B. nanae were 0.060 (SE+/- 0.011) and 0.019 (SE+/- 0.006) for COI, and 0.073 (SE+/- 0.011) and $0.038(\mathrm{SE}+/-0.010)$ for $16 \mathrm{~S}$, respectively.

The phylogeny confirmed the monophyly of both $B$. nanae and $B$. magnum. The analysis suggests that $B$. nanae is sister taxon for B. zeteki, while B. magnum was paired with B. nanae + B. zeteki clade (Figure 1).

TABLE 1. COI Kimura two-parameter (2-p) divergence distances (lower-left) and standard errors of each comparison (upper-right) between known species of Bimastos (for which sequence data are available). Divergence distances are expressed as the proportion of base pair differences.

\begin{tabular}{lllllllllll}
\hline & 1. & 2. & 3. & 4. & 5. & 6. & 7. & 8. & 9. & 10. \\
\hline 1. B. eiseni & & 0.022 & 0.019 & 0.020 & 0.019 & 0.023 & 0.020 & 0.021 & 0.022 & 0.021 \\
2. B. heimburgeri & 0.175 & & 0.020 & 0.020 & 0.019 & 0.023 & 0.021 & 0.023 & 0.019 & 0.021 \\
3. B. longicinctus & 0.166 & 0.155 & & 0.022 & 0.019 & 0.019 & 0.018 & 0.022 & 0.020 & 0.018 \\
4. B. palustris & 0.152 & 0.137 & 0.171 & & 0.021 & 0.021 & 0.022 & 0.021 & 0.021 & 0.020 \\
5. B. parvus & 0.144 & 0.127 & 0.144 & 0.127 & & 0.023 & 0.019 & 0.021 & 0.019 & 0.019 \\
6. B. schwerti & 0.169 & 0.175 & 0.154 & 0.164 & 0.147 & & 0.024 & 0.023 & 0.022 & 0.021 \\
7. B. tumidus & 0.170 & 0.156 & 0.142 & 0.136 & 0.154 & 0.196 & & 0.020 & 0.021 & 0.021 \\
8. B. rubidus & 0.177 & 0.178 & 0.183 & 0.139 & 0.134 & 0.176 & 0.147 & & 0.022 & 0.021 \\
9. B. magnum & 0.185 & 0.144 & 0.168 & 0.139 & 0.153 & 0.168 & 0.159 & 0.177 & & 0.019 \\
10. B. nanae & 0.157 & 0.145 & 0.147 & 0.126 & 0.128 & 0.140 & 0.166 & 0.151 & 0.140 & \\
\hline
\end{tabular}


TABLE 2. 16S Kimura two-parameter (2-p) divergence distances (lower-left) and standard errors of each comparison (upper-right) between known species of Bimastos (for which sequence data are available). Divergence distances are expressed as the proportion of base pair differences.

\begin{tabular}{lllllllllllll}
\hline & 1. & 2. & 3. & 4. & 5. & 6. & 7 & 8. & 9. & 10. & 11. & 12. \\
\hline 1. B. eiseni & & 0.013 & 0.013 & 0.015 & 0.011 & 0.014 & 0.016 & 0.012 & 0.016 & 0.014 & 0.017 & 0.016 \\
2. B. heimburgeri & 0.079 & & 0.013 & 0.013 & 0.013 & 0.015 & 0.015 & 0.013 & 0.014 & 0.010 & 0.013 & 0.013 \\
3. B. longicinctus & 0.083 & 0.091 & & 0.015 & 0.012 & 0.015 & 0.015 & 0.015 & 0.012 & 0.013 & 0.014 & 0.015 \\
4. B. palustris & 0.106 & 0.108 & 0.123 & & 0.015 & 0.017 & 0.016 & 0.011 & 0.016 & 0.013 & 0.015 & 0.017 \\
5. B. parvus & 0.085 & 0.099 & 0.101 & 0.111 & & 0.014 & 0.015 & 0.011 & 0.015 & 0.014 & 0.017 & 0.015 \\
6. B. schwerti & 0.092 & 0.081 & 0.109 & 0.106 & 0.110 & & 0.018 & 0.015 & 0.017 & 0.015 & 0.015 & 0.015 \\
7. B. tumidus & 0.123 & 0.116 & 0.121 & 0.121 & 0.112 & 0.125 & & 0.016 & 0.018 & 0.015 & 0.016 & 0.016 \\
8. B. rubidus & 0.082 & 0.092 & 0.104 & 0.092 & 0.060 & 0.102 & 0.130 & & 0.015 & 0.013 & 0.014 & 0.015 \\
9. B. welchi & 0.108 & 0.098 & 0.088 & 0.111 & 0.103 & 0.122 & 0.132 & 0.093 & & 0.014 & 0.016 & 0.017 \\
10. B. zeteki & 0.095 & 0.073 & 0.092 & 0.103 & 0.098 & 0.091 & 0.126 & 0.091 & 0.098 & & 0.013 & 0.011 \\
11. B. magnum & 0.130 & 0.109 & 0.112 & 0.135 & 0.138 & 0.122 & 0.151 & 0.138 & 0.134 & 0.110 & & 0.015 \\
12. B. nanae & 0.102 & 0.085 & 0.104 & 0.125 & 0.103 & 0.099 & 0.119 & 0.095 & 0.106 & 0.054 & 0.123 & \\
\hline
\end{tabular}

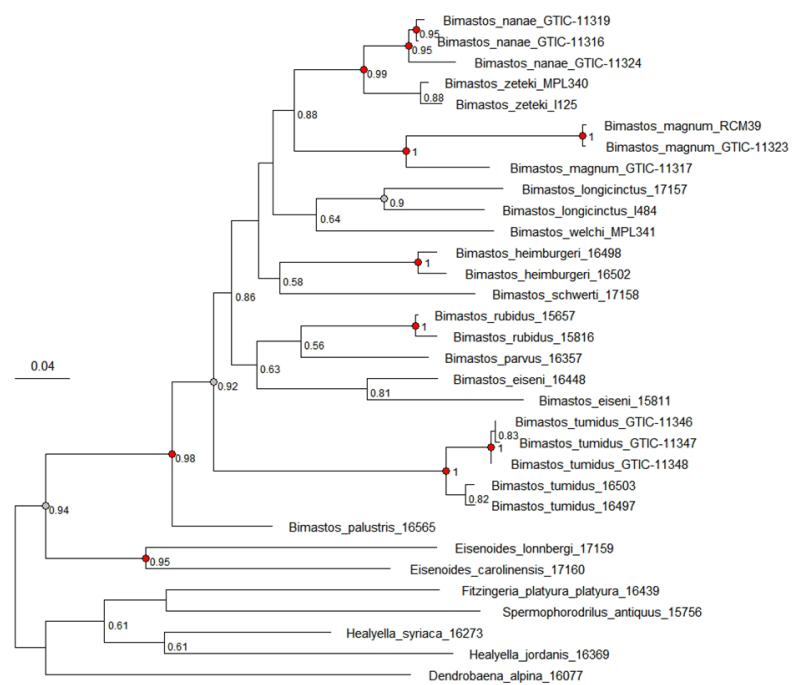

FIGURE 1. Maximum Likelihood phylogenetic analysis of the concatenated $16 \mathrm{~S}$ and COI genes. Branch support are Transfer Bootstrap Expectation (TBE), nodes with a light grey circle have TBE $\geq 0.90$, with red circles (dark grey in printed version), $\geq$ 0.95. Nodes without numbers or circles have TBE $<0.50$. Branch length represents number of substitutions per site, given the available data (see Appendix 1).

\section{Taxonomy}

\section{Bimastos Moore, 1893}

For diagnosis and full list of synonyms for the genus, see Csuzdi et al. (2017).

\section{Bimastos nanae Carrera-Martínez n. sp.}

Figure $2 \mathrm{~A}, \mathrm{C}$

urn:lsid:zoobank.org:act:907B4103-225D-41F5-BC5B-37C3EB3A421B

Holotype. Adult (GTIC-11519), collected from topsoil, under mosses and leaf litter in saturated soil near Dismal Creek at 730-800 m elevation, Chattahoochee National Forest, Towns Co., GA, USA (34.893879N, 83.660047W), Cols. SW James, MA Callaham Jr, MK Taylor, BA Snyder, R Carrera-Martínez, 26.SEP.2017. 
Paratypes. One adult collected with Holotype (GTIC-11516). One early adult (GTIC-11540) collected by grunting near Bombing Rd, south of Isaacs Creek at 140 m elevation, Sumter National Forest, Union Co., SC, USA (34.647609N, 81.732213W), Cols. R Carrera-Martínez, MK Taylor, MA Callaham Jr, 07.MAR.2017. One adult (GTIC-11522), ca. $600 \mathrm{~m}$ west of Tate City Rd. and $320 \mathrm{~m}$ east of Sassafras Branch, at 1,012 m altitude, Nantahala National Forest, Clay Co., NC, USA, Cols. MK Taylor, GL Chapman, DO Carpenter, 21.NOV.2018. One adult (GTIC-11524) Quiet Walkway, N of Carlos Campbell Overlook, GSMNP, Sevier Co. TN., USA, Cols. MA Callaham, MK Taylor, 01.NOV.2017.

Etymology: This species is named in loving memory of Nan Christine Hediger, mother of Dana O. Carpenter, who collected part of the type series.

\section{External characteristics (Figure 2A):}

Length 58-80 mm. Diameter at x 3.4-5.0 mm, at the clitellum 5.0-6.0 mm. Number of segments 130-149, simple annulation. Live specimen brown; preserved, body light violet-reddish dorsally, clitellum pale to pinkish-white. Prostomium epilobic, narrow and open, extends through about $2 / 3$ of the peristomium. First dorsal pore in $4 / 5$ or $5 / 6$. Spermathecal pores absent. Female pores in xiv, lateral and next to $b$, small but visible. Male pores equatorial and conspicuous with associated swelling between $b c$, closer to $b$. Clitellum in xxvi-xxxv, saddle-shaped, ventral limit in $b$ in xxvi-xxvii, $a$ in xviii-xxxv. Tubercula pubertatis absent. No genital markings were observed. Nephridiopores, when visible, forming a regular row dorsal to $d$. Setae, lumbricine, 8 per segment, closely paired. In $\mathrm{x} a a: a b: b c$ : $c d: d d=5.21: 1.17: 3.75: 1.00: 13.33$, in $\mathrm{xl}=10.00: 1.00: 6.25: 1.00: 26.50 ; c d$ at the mid-lateral line throughout (Figure $2 \mathrm{C})$. All setae unmodified.
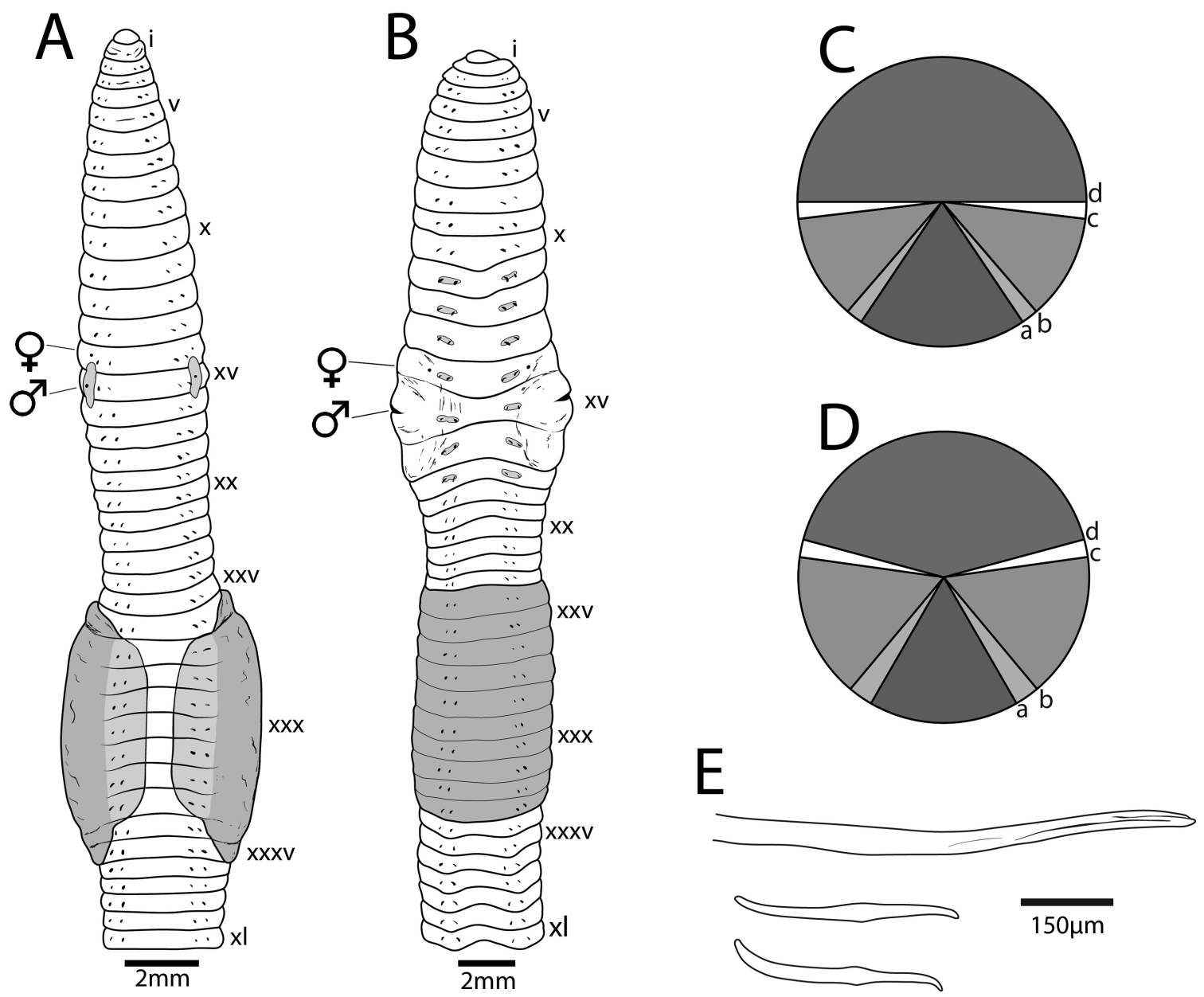

FIGURE 2. External morphology of (A) Bimastos nanae n. sp. and (B) Bimastos magnum n. sp. based on their holotypes; setae distribution in xl of (C) B. nanae n. sp. and (D) B. magnum n. sp.; and (E, top) distal end of the copulatory setae of segment $\mathrm{xv}$ of $B$. magnum n. sp. holotype and somatic setae $a b$ of xviii (E, center and bottom), scale on $\mathrm{E}$ is the same for all three setae. In $\mathrm{A}$ and $\mathrm{B}, \mathrm{q}$ : female pore and $\widehat{\supset}:$ male pore. 


\section{Internal anatomy:}

Septa 5/6-10/11 pushed backwards, 6/7-8/9 thickened, 5/6 and 9/10 slightly thickened, 15/16-17/18 very thin and delicate. Pharynx ends in iv, associated with many muscular fibers attached to body wall. Calciferous sacks medium to large in $\mathrm{x}$, calciferous glands in xi-xii not interrupted by 11/12 septum. Crop in xiv-xv, subdivided into two sections of similar size by septum 14/15. Gizzard, large and muscular in xvii-xviii, valve in 18/19. Intestinal origin abrupt in xix. Typhlosole arising in xxi, bifid or Y-shaped, increasing in size progressively, occupying the entire lumen of the intestine in the posterior half of the body, before ending abruptly in the region of xciii. Hearts in vii-xi, largest in x. Dorsal and ventral trunks simple, dorsal first visible at vii. Anterior to vii, only small lateral commissures can be observed. Holonephridia paired, one per segment, with tubular bladder U-shaped with proclinate ental limb, extending to $d$, parallel to the much thinner vesicles, with constant shape and size throughout the body. Spermathecae absent. Ovaries, bundle-like in xiii. Testes free in $\mathrm{x}$ and xi. Seminal vesicles large and free, covering the intestinal tract completely in xi and xii only. Prostates absent. No iridescence observed in reproductive organs.

Remarks: Bimastos nanae n. sp. resembles B. lawrenceae Fender 1994, B. zeteki (Smith \& Gittins 1915) and $B$. welchi (Smith 1917), since all have the clitellum located in the same general area. However, B. nanae has its clitellum located in xxvi-xxxv, whereas $B$. lawrenceae has it in xxv-xxxiv, $B$. zeteki in xxvii-xxxvii, xxxviii and $B$. welchi in xxv-xxxv. Additionally, $B$. nanae differs from $B$. zeteki and $B$. lawrenceae in having less pigmentation and from $B$. zeteki and $B$. welchi on having a smaller size. The size and number of segments of $B$. lawrenceae is not mentioned in its original description, but the shorter extension of the calciferous glands in $B$. nanae, different typhlosolar origin (xxi in B. nanae vs. xxii-xxiii in B. lawrenceae), different location of thickened septa (7/8-8/9 in B. nanae, vs. $12 / 13-14 / 15$ only slightly in B. lawrenceae), and different setal ratios can be used to differentiate both species. Table 3 summarizes differences between these species.

TABLE 3. Differences between Bimastos nanae n. sp. and morphologically similar species. Morphological data for all previously described species obtained from Csuzdi et al. (2017) and their original descriptions (McKey-Fender et al. 1994; Smith 1917; Smith \& Gittins 1915). Question marks represent unknown characters.

\begin{tabular}{|c|c|c|c|c|}
\hline Characters & B. nanae n. sp. & $\begin{array}{l}\text { B. lawrenceae } \\
\text { Fender, } 1994\end{array}$ & $\begin{array}{c}\text { B. welchi } \\
\text { Smith, } 1917\end{array}$ & $\begin{array}{c}\text { B. zeteki } \\
\text { Smith \& Gittins, } 1915 \\
\end{array}$ \\
\hline Length (mm) & $58-80$ & $?$ & 135 & $100-140$ \\
\hline Diameter (mm) & $4.5-6.0$ & $?$ & 4.5 & $5.0-6.5$ \\
\hline No. of segments & $130-150$ & $?$ & 116 & $134-142$ \\
\hline Pigmentation & Light violet & Red & Pale & Violet \\
\hline Clitellum & xxvi-xxxy & xxv-xxxiv & $x x v-x x x y$ & xxvii-xxxvii, xxxviii \\
\hline Setal ratio & $a a>b c, a b \approx c d$ & $a a \approx b c, a b \approx c d$ & $a a>b c, a b>c d$ & $a a>b c, a b=c d$ \\
\hline Thickened septa & $\begin{array}{l}\text { 6/7-8/9 strongly, 5/6, } \\
\text { 9/10 slightly }\end{array}$ & $\begin{array}{l}12 / 13-14 / 15 \\
\text { moderately }\end{array}$ & $\begin{array}{c}\text { 8/9-11/12 strongly, } \\
6 / 7-7 / 8,12 / 13 \\
\text { slightly }\end{array}$ & $\begin{array}{c}\text { 7/8-12/13 slightly, } 13 / 14- \\
14 / 15 \text { moderately }\end{array}$ \\
\hline Calciferous glands & $\begin{array}{l}\text { xi-xii, medium to } \\
\text { large diverticula in } x\end{array}$ & $\begin{array}{l}\text { xi-xiii, diverticula } \\
\text { in } \mathrm{x}\end{array}$ & $\begin{array}{c}\text { xi-xii, small } \\
\text { diverticula in } x\end{array}$ & $x i-x i i$, small diverticula in $\mathrm{x}$ \\
\hline Typhlosole & Bifid or Y-shaped & Bifid or Y-shaped & $?$ & Lamelliform \\
\hline
\end{tabular}

\section{Bimastos magnum Carrera-Martínez n. sp.}

Figure 2 B, D, E

urn:1sid:zoobank.org:act:E3A5D18A-40D1-4C25-80C8-E978ADAF9CD2

Holotype. One adult (GTIC-11517), collected from topsoil, under mosses and leaf litter in saturated soil near Dismal Creek at 730-800 m elevation, Chattahoochee National Forest, Towns Co., GA, USA (34.893879N, 83.660047W), Cols. SW James, MA Callaham, MK Taylor, BA Snyder, R Carrera-Martínez, 26.SEP.2017.

Paratype. Two adults (GTIC-11518, GTIC-11520), collected with Holotype. One adult (GTIC-11523), Chattahoochee NF, Murray Co., GA, USA $(34.8664 \mathrm{~N}, 84.6438 \mathrm{~W})$, Cols. MA Callaham, MK Taylor, 05.OCT.2017. 
Etymology: From magnus, Latin for large, or huge, in reference to its generally large size relative to other species in the genus, and specifically to its male pores and porophores.

TABLE 4. Differences between Bimastos magnum n. sp. and other Bimastos species with annular clitellum. Morphological data for B. palustris obtained from Moore (1895) and Csuzdi et al. (2017) and for B. schwerti, from Csuzdi et al. (2017).

\begin{tabular}{lccc}
\hline Characters & B. magnum n. sp. & $\begin{array}{c}\text { B. palustris } \\
\text { Moore, 1895 }\end{array}$ & $\begin{array}{c}\text { B. schwerti } \\
\text { Csuzdi and Chang, 2017 }\end{array}$ \\
\hline Length $(\mathrm{mm})$ & $65-120$ & $18-30$ & $25-62$ \\
Diameter (mm) & $4.2-4.8$ & $1.5-2.5$ & $2.0-5.0$ \\
No. of segments & $118-152$ & $80-100$ & $88-120$ \\
Pigmentation (preserved) & Reddish dorsally & Pale with reddish dorsum & Brown (red-violet alive) \\
Clitellum & xxiv-xxxiii, xxxiv & xxiii-xxviii & xxi, xxii, xxiii-xxx \\
Setal ratio & $a a \approx b c, a b>c d$ & $a a>b c, a b>c d$ & $a a \approx b c, a b>c d$ \\
Copulatory setae & xi-xvii & Absent & Absent \\
Thickened septa & $5 / 6-12 / 13$ thickened, & $7 / 8-8 / 9$ slightly & $6 / 7-8 / 9,12 / 13-14 / 15$ moderately; \\
& $4 / 5,13 / 14-14 / 15$ slightly & $9 / 10-10 / 11$ slightly \\
Calciferous glands & xi-xii, $(1 / n)$ xiii, large & x-xii, moderate & x-xiii, small diverticula in x \\
& diverticula in x & diverticula in $x$ & Bifid or Y-shaped \\
\hline
\end{tabular}

\section{External characteristics (Figure 2B):}

Length 66-120 mm. Diameter at x 4.5-4.6 mm, at the clitellum 4.2-4.8 mm. Number of segments 118-152, vi-xvii with dorsal secondary annulation between $d d$. Live specimen red to brown-red; preserved, body and clitellum almost completely white, reddish on the anterior dorsum. Prostomium epilobic, narrow and open, extends through about $2 / 3$ of the peristomium. First dorsal pore small in $4 / 5$, after $5 / 6$, dorsal pores larger. Spermathecal pores inconspicuous. Female pores in xiv, next to $b$, slightly presetal, conspicuous. Male pores equatorial, conspicuous with associated porophores extending into part of xiv and xvi, midway between $b c$. Clitellum in xxiv-xxxiii, xxxiv, annular, uniformly developed ventrally. Tubercula pubertatis absent. Genital markings surrounding $a b$ on xi-xvii, xviii. Nephridiopores, when visible, at or dorsal to $d$. Setae, lumbricine, 8 per segment, closely paired: in $\mathrm{x} a a: a b$ : $b c: c d: d d=8.56: 1.44: 9.44: 1.00: 23.89$, in $\mathrm{xl}=8.50: 1.40: 8.22: 1.00: 21.22$ (Figure 2D). Setae all small, difficult to observe externally, smooth, ca. $300 \mu \mathrm{m}$ long and $35 \mu \mathrm{m}$ wide; $a b$ modified as copulatory setae in xi-xvii; in xv, ca. $1.3 \mathrm{~mm}$ long, 50-51 $\mu \mathrm{m}$ midpoint diameter, smooth throughout, blunt tip (Figure 2E).

\section{Internal anatomy:}

Septa 4/5, 13/14-14/15 slightly thickened, 5/6-12/13 thickened. Well-developed pharynx ends in iv. Calciferous diverticula huge in $\mathrm{x}$, calciferous glands in xi-xii, partially extending into xiii. Crop in xiv-xv, subdivided into two sections of similar size by septum 14/15. Gizzard large and muscular in xvi-xvii, valve in 17/18. Intestinal origin abrupt in xviii. Typhlosole arising in xviii, bifid or Y-shaped, increasing in size progressively, occupying about 1/3 of the diameter of the lumen of the intestine at xxv. Hearts in vii-xi, largest in x. Dorsal and ventral trunks simple. Anterior to vii, small lateral commissures present. Holonephridia paired, one per segment, with tubular bladder U-shaped, extending dorsal to $d$, parallel to the much thinner vesicles, posterior to xv, bladder progressively gains a long J-shape. Paired spermathecae present in xiii-xvii, ventral. Ovaries, fan-like in xiii. Testes free in $\mathrm{x}$ and xi. Seminal vesicles big and free, covering the intestinal tract completely in $\mathrm{x}$, $\mathrm{xi}$ and xii, iridescent. Prostates absent.

Remarks: Bimastos magnum n. sp. is the only known species in the genus to possess copulatory setae and spermathecae; it is the third possessing a completely annular clitellum and male pores on large porophores extending into adjacent segments, with the other two being B. palustris Moore, 1895 and B. schwerti Csuzdi and Chang, 2017. Bimastos magnum differs from these species in the position of its clitellum (xxiv-xxxiii, xxxiv) and size (65-120 
$\mathrm{mm}$ ) as both, B. palustris and B. schwerti, have a more anteriorly placed clitellum (xxiii-xxviii and xxiii-xxx, respectively) and are smaller (18-30 and 25-62 mm, respectively). Table 4 summarizes differences between these species. Bimastos magnum is among the largest known species of the genus, comparable to, or only slightly smaller than B. zeteki and B. welchi. Bimastos magnum is the second Bimastos species to have spermathecae, with $B$. rubidus occasionally presenting spermathecae in ix and $\mathrm{x}$. It is unknown how prevalent, functional, or variable are the presence of spermathecae in B. magnum, some of which were iridescent.

\section{Discussion}

Following the key to Bimastos species from Csuzdi et al. (2017), B. nanae n. sp. will key to couplet 5, where $B$. welchi and B. lawrenceae are the only options. Bimastos nanae n. sp. differs from these species by having the clitellum in xxvi-xxxv, a ratio between $a b: c d$, and in the location of the thickened septa (Table 3). Bimastos magnum n. sp. will key to couplet 2 in Csuzdi et al. (2017), where B. palustris and B. schwerti are the only options. Bimastos magnum n. sp. differs from both species by its lager size $(65-120 \mathrm{~mm})$ and in having the clitellum in xxiv-xxxiii, xxxiv (Table 4). Bimastos magnum is unique in the genus by having copulatory setae and spermatheca. Bimastos rubidus occasionally has spermathecae, but these are usually small and empty, however no other known Bimastos species has copulatory setae. Nonetheless, the lack of tubercula pubertatis, having calciferous diverticula in $\mathrm{x}$, and pigmentation and u-shaped nephridial bladder supports its placement within Bimastos (Csuzdi et al. 2017; Gates 1969), as supported by our phylogenetic analysis (Figure 1).

According to our phylogenetic inference (Figure 1), B. nanae is closest to B. zeteki, while B. magnum is the sister taxon to the clade formed by $B$. nanae and $B$. zeteki (although with relatively weak support). This suggests that the development of large porophores and prescence of spermathecae has been either gained or lost multiple times within Bimastos. Nonetheless, we also note the relatively short branches (as seen in Csuzdi et al. 2017) and weak support $(\mathrm{TBE}<0.90)$ for the deeper clades of the genus. This might indicate a rapid species radiation event, however further studies are needed to confirm this hypothesis and confirm the evolutionary history of the group.

With the description of B. nanae and B. magnum, the number of valid species of Bimastos is raised to 14 species (Csuzdi et al. 2017). Most of these species are found in eastern North America, including the two described here. Bimastos welchi Smith, 1917, is found in the Great Plains region of North America, whereas B. lawrenceae Fender, 1994, is the only species endemic to the Pacific Coast, where it is so far limited to Vancouver Island (Csuzdi et al. 2017; McKey-Fender et al. 1994; Smith 1917). Together, Bimastos and Eisenoides form a monophyletic group endemic to North America, and are sister taxa to the mostly temperate Eurasian Eisenia (Csuzdi et al. 2017). This divergence has been dated back to the Late Cretaceous (Domínguez et al. 2015) but there is still uncertainty about how the Bimastos-Eisenoides clade arrived in North America (Csuzdi et al. 2017). It is notable that the earthworm diversity of the Pacific Northwestern coast of North America has been sorely neglected for the last 30+ years, but there are reports of extensive, undescribed diversity present in that region (Fender 1995; Fender \& McKeyFender 1990). Additionally, many undescribed species of earthworms are still being collected (Csuzdi et al. 2017; Damoff \& Reynolds 2017). Therefore, we expect that further collecting across North America will yield additional undescribed species that will be referable to the Bimastos-Eisenoides clade.

Both B. nanae and B. magnum (and most of the Bimastos species) occur in the Appalachian Mountains and Piedmont region. Several lines of evidence suggest that the ecosystems of the Southern Appalachians developed under the influence of frequent fires, and that most areas burned every 2-20 years. However, the recent (postEuropean settlement) history of the region has been one of nearly complete fire suppression (Flatley et al. 2013; Lafon et al. 2017). It therefore seems reasonable to suppose that any native earthworm fauna would be adapted to frequent fires, and indeed both specimens described here seem to have epi-endogeic habits which essentially protects them from receiving direct effects of fire (Certini et al. 2021; Ikeda et al. 2015). Interestingly, several species of Bimastos have the habit of living inside the bark of decomposing trees (thus, the common name of American log worm or bark worm [James 1995; Reynolds 1977]), and this too would likely be a low-risk place to weather low-intensity surface fires that are characteristic of frequently burned ecosystems. This open niche could have perhaps resulted in a species radiation event discussed earlier (Martin \& Richards 2019). In any case, the effect of reintroducing fire into these ecosystems after decades of fire suppression on the earthworm fauna, native or introduced needs to be addressed (but see Ikeda et al. 2015). 
Appendix 1. Accession number for all COI and 16S DNA sequences. Specimens with asterisks are the holotype of $B$. magnum and B. nanae. Numbers after specimens from Csuzdi et al. (2017) refers to their Hungarian Natural History Museum (HNHM) catalog numbers.

\begin{tabular}{|c|c|c|c|}
\hline Species and specimen ID & COI & $16 \mathrm{~S}$ & Reference \\
\hline Bimastos eiseni HNHM-15811 & KX651115 & - & Csuzdi et al. (2017) \\
\hline Bimastos eiseni HNHM-16448 & KX651116 & KX651221 & Csuzdi et al. (2017) \\
\hline Bimastos heimburgeri HNHM-16498 & KX651119 & KX651224 & Csuzdi et al. (2017) \\
\hline Bimastos heimburgeri HNHM-16502 & KX651120 & KX651225 & Csuzdi et al. (2017) \\
\hline Bimastos longicinctus HNHM-017157 & KX651137 & KX651240 & Csuzdi et al. (2017) \\
\hline Bimastos longicinctus 1484 & LC475696 & LC476001 & Ikeda et al. (2020) \\
\hline Bimastos magnum GTIC-11517* & OK104083 & OK143525 & This study \\
\hline Bimastos magnum GTIC-11523 & OK104085 & OK143527 & This study \\
\hline Bimastos magnum RCM39 & OK104084 & OK143526 & This study \\
\hline Bimastos nanae GTIC-11516 & OK104086 & OK143523 & This study \\
\hline Bimastos nanae GTIC-11519* & OK104088 & - & This study \\
\hline Bimastos nanae GTIC-11524 & OK104087 & OK143524 & This study \\
\hline Bimastos palustris HNHM-16565 & KX651121 & KX651226 & Csuzdi et al. (2017) \\
\hline Bimastos parvus HNHM-16357 & KX651122 & KX651227 & Csuzdi et al. (2017) \\
\hline Bimastos rubidus HNHM-15657 & KX651130 & KX651234 & Csuzdi et al. (2017) \\
\hline Bimastos rubidus HNHM-15816 & KX651131 & KX651235 & Csuzdi et al. (2017) \\
\hline Bimastos schwerti HNHM-17158 & KX651138 & KX651241 & Csuzdi et al. (2017) \\
\hline Bimastos tumidus HNHM-16497 & KX651123 & - & Csuzdi et al. (2017) \\
\hline Bimastos tumidus HNHM-16503 & KX651124 & KX651228 & Csuzdi et al. (2017) \\
\hline Bimastos tumidus GTIC-11546 & OK104080 & - & This study \\
\hline Bimastos tumidus GTIC-11547 & OK104081 & - & This study \\
\hline Bimastos tumidus GTIC-11548 & OK104082 & - & This study \\
\hline Bimastos welchi MPL241 & - & KJ912520 & Domínguez et al. (2013) \\
\hline Bimastos zeteki 1125 & - & LC475991 & Ikeda et al. (2020) \\
\hline Bimastos zeteki MPL340 & - & KJ912521 & Domínguez et al. (2013) \\
\hline Eisenoides carolinensis HNHM-17160 & KX651140 & KX651243 & Csuzdi et al. (2017) \\
\hline Eisenoides lonnbergi HNHM-17159 & KX651139 & KX651242 & Csuzdi et al. (2017) \\
\hline Healyella jordanis HNHM-16369 & KX651133 & KX651237 & Csuzdi et al. (2017) \\
\hline Healyella syriaca HNHM-16273 & KX651134 & - & Csuzdi et al. (2017) \\
\hline Fitzingeria platyura platyura HNHM-16439 & KX651141 & KX651245 & Csuzdi et al. (2017) \\
\hline Spermophorodrilus antiquus HNHM-15756 & KX651136 & - & Csuzdi et al. (2017) \\
\hline Dendrobaena alpina HNHM-16077 & KX651125 & KX651229 & Csuzdi et al. (2017) \\
\hline
\end{tabular}

\section{Acknowledgements}

We thank Samuel W. James, Melanie K. Taylor, Dana O. Carpenter, and Nina Wurzburger for assisting in one way or another in the collection of the type series of both newly described species. We are also grateful for the support of Madeline N. Olliff for her valuable assistance during DNA extraction. Earthworm collection was performed under the permits GRSM-2017-SCI-2027 (for collections at Great Smoky Mountains National Park in Tennessee), and with the kind permission of the Forest Supervisor's offices of the Chattahoochee-Oconee and Nantahala National Forests (for sampling in Georgia and North Carolina). This research was supported in part by USDA Forest Service agreement 17-JV-11330136-062 with Georgia College. We are also grateful for the constructive comments provided by two anonymous reviewers that improved earlier versions of the manuscript. 


\section{References}

Bouché, M.B. (1975) La reproduction de Spermophorodrilus albanianus nov. gen. nov. sp. (Lumbricidae) explique- t-elle la fonction des spermatophores? Zoologische Jahrbücher Abteilung für Systematik Ökologie und Geographie der Tiere, 102, $1-11$.

Capella-Gutiérrez, S., Silla-Martínez, J.M. \& Gabaldón, T. (2009) trimAl: A tool for automated alignment trimming in largescale phylogenetic analyses. Bioinformatics, 25, 1972-1973.

https://doi.org/10.1093/bioinformatics/btp348

Carpenter, D.O., Taylor, M.K., Callaham, M.A., Hiers, J.K., Loudermilk, E.L., O’Brien, J.J. \& Wurzburger, N. (2021) Benefit or liability? The ectomycorrhizal association may undermine tree adaptations to fire after long-term fire exclusion. Ecosystems, 24, 1059-1074. https://doi.org/10.1007/s10021-020-00568-7

Certini, G., Moya, D., Lucas-Borja, M.E. \& Mastrolonardo, G. (2021) The impact of fire on soil-dwelling biota: A review. Forest Ecology and Management, 488, 118989. https://doi.org/10.1016/j.foreco.2021.118989

Csuzdi, C., Chang, C.H., Pavlícek, T., Szederjesi, T., Esopi, D. \& Szlávecz, K. (2017) Molecular phylogeny and systematics of native North American lumbricid earthworms (Clitellata: Megadrili). PloS one, 12 (8), e0181504. https://doi.org/10.1371/journal.pone.0181504

Damoff, G.A. \& Reynolds, J.W. (2017) Diplocardia deborahae, a new earthworm species (Annelida: Oligochaeta: Acanthodrilidae) from Eastern Tennessee, USA. Megadrilogica, 22, 229-237.

Domínguez, J., Aira, M., Breinholt, J.W., Stojanovic, M., James, S.W. \& Pérez-Losada, M. (2015) Underground evolution: New roots for the old tree of lumbricid earthworms. Molecular Phylogenetics and Evolution, 83, 7-19. https://doi.org/10.1016/j.ympev.2014.10.024

Fender, W.M. (1995) Native earthworms of the Pacific Northwest: An ecological overview. In: Hendrix, P.F. (Ed.), Earthworm ecology and biogeography in North America. CRC Press, Inc., Boca Raton, Florida, pp. 52-66.

Fender, W.M. \& McKey-Fender, D. (1990) Oligochaeta: Megascolesidae and other earthworms from Western North America. In: Dindal, D.L. (Ed.), Soil Biology Guide. John Wiley \& Sons, Inc., New York, New York, pp. 357-378.

Flatley, W.T., Lafon, C.W., Grissino-Mayer, H.D. \& LaForest, L.B. (2013) Fire history, related to climate and land use in three southern Appalachian landscapes in the eastern United States. Ecological Applications, 23, 1250-1266. https://doi.org/10.1890/12-1752.1

Folmer, O., Black, M., Hoeh, W., Lutz, R. \& Vrijenhoek, R. (1994) DNA primers for amplification of mitochondrial cytochrome c oxidase subunit I from diverse metazoan invertebrates. Molecular Marine Biology and Biotechnology, 3, $294-299$.

Gates, G.E. (1969) On two American genera of the earthworm family Lumbricidae. Journal of Natural History, 3, $305-307$. https://doi.org/10.1080/00222936900770261

Ikeda, H., Callaham, M.A., O’Brien, J.J., Hornsby, B.S. \& Wenk, E.S. (2015) Can the invasive earthworm, Amynthas agrestis, be controlled with prescribed fire? Soil Biology and Biochemistry, 82, 21-27. https://doi.org/10.1016/j.soilbio.2014.12.011

Ikeda, H., Callaham, M.A., Shefferson, R.P., Wenk, E.S. \& Fragoso, C. (2020) A comparison of latitudinal species diversity patterns between riverine and terrestrial earthworms from the North American temperate zone. Journal of Biogeography, $47,1373-1382$. https://doi.org/10.1111/jbi.13826

James, S.W. (1995) Systematics, biogeography and ecology of earthworms from eastern, central, southern and southwestern USA. In: Hendrix, P.F. (Ed.), Earthworm Ecology and Biogeography in North America. CRC Press, Inc., Boca Raton, Florida, pp. 29-51.

Jolly, W.M., Cochrane, M.A., Freeborn, P.H., Holden, Z.A., Brown, T.J., Williamson, G.J. \& Bowman, D.M.J.S. (2015) Climateinduced variations in global wildfire danger from 1979 to 2013. Nature Communications, 6, art. 7537. https://doi.org/10.1038/ncomms8537

Kalyaanamoorthy, S., Minh, B.Q., Wong, T.K.F., von Haeseler, A. \& Jermiin, L.S. (2017) ModelFinder: Fast model selection for accurate phylogenetic estimates. Nature Methods, 14, 587-589. https://doi.org/10.1038/nmeth.4285

Kimura M. (1980). A simple method for estimating evolutionary rate of base substitutions through comparative studies of nucleotide sequences. Journal of Molecular Evolution, 16, 111-120. https://doi.org/10.1007/BF01731581

Kozlov, A.M., Darriba, D., Flouri, T., Morel, B. \& Stamatakis, A. (2019) RAxML-NG: A fast, scalable and user-friendly tool for maximum likelihood phylogenetic inference. Bioinformatics, 35, 4453-4455. https://doi.org/10.1093/bioinformatics/btz305

Kumar, S., Stecher, G., Li, M., Knyaz, C. \& Tamura, K. (2018) MEGA X: Molecular evolutionary genetics analysis across computing platforms. Molecular Biology and Evolution, 35, 1547-1549. https://doi.org/10.1093/molbev/msy096

Lafon, C.W., Naito, A.T., Grissino-Mayer, H.D., Horn, S.P. \& Waldrop, T.A. (2017) Fire history of the Appalachian region: A review and synthesis. General Technical Report, SRS-219, 97.

https://doi.org/10.2737/SRS-GTR-219 
Lemoine, F., Domelevo Entfellner, J.-B., Wilkinson, E., Correia, D., Dávila Felipe, M., De Oliveira, T. \& Gascuel, O. (2018) Renewing Felsenstein's phylogenetic bootstrap in the era of big data. Nature, 556, 452-456. https://doi.org/10.1038/s41586-018-0043-0

Luna-Vega, I. \& Contreras-Medina, R. (2010) Plant biodiversity hotspots and biogeographic methods. In: Rescigno, V. \& Maletta, S. (Eds.), Biodiversity Hotspots. Nova Science Publishers, New York, New York, pp. 181-191.

Martin, C.H. \& Richards, E.J. (2019) The paradox behind the pattern of rapid adaptive radiation: How can the speciation process sustain itself through an early burst? Annual Review of Ecology, Evolution, and Systematics, 50, 569-593. https://doi.org/10.1146/annurev-ecolsys-110617-062443

McKey-Fender, D., Fender, W.M. \& Marshall, V.G. (1994) North-American earthworms native to Vancouver-Island and the Olympic Peninsula. Canadian Journal of Zoology-Revue Canadienne De Zoologie, 72, 1325-1339. https://doi.org/10.1139/z94-176

Michaelsen, W. (1899) Die Lumbriciden-fauna Nordamerikas. Abhandlungen und Verhandlungen des Naturwissenschaftlichen Vereins in Hamburg, 28, 421-454.

Michaelsen, W. (1900) 10. Lieferung. Oligochaeta. In: J.W. Spengel (Ed.), Vermes. In: Schulze, F.E. (Ed.), Das Tierreich. Verlag von R. Friedländer und Sohn, Berlin, pp. 1-575.

Milanovich, J.R., Peterman, W.E., Nibbelink, N.P. \& Maerz, J.C. (2010) Projected loss of a salamander diversity hotspot as a consequence of projected global climate change. PLoS one, 5, e12189. https://doi.org/10.1371/journal.pone.0012189

Moore, H.F. (1893) Preliminary account of a new genus of Oligochaeta. Zoologischer Anzeiger, 16, 333-334.

Moore, H.F. (1895) On the structure of Bimastos palustris, a new oligochaete. Journal of Morphology, 10, 473-496.

Mršić, N. (1990) Description of a new subgenus, three new species and taxonomic problems of the genus Allolobophora sensu Mršić \& Šapkarev 1988 (Lumbricidae, Oligochaeta). Bioloski vestnik Lubljana, 38, 46-68.

Mršić, N. (1991) Monographs of Earthworms on the Balkans I-II. SAZU, Ljubljana, 757 pp.

Nguyen, L.-T., Schmidt, H.A., von Haeseler, A. \& Minh, B.Q. (2015) IQ-TREE: A Fast and Effective Stochastic Algorithm for Estimating Maximum-Likelihood Phylogenies. Molecular Biology and Evolution, 32, 268-274. https://doi.org/10.1093/molbev/msu300

Novo, M., Almodóvar, A., Fernández, R., Trigo, D. \& Díaz Cosín, D.J. (2010) Cryptic speciation of hormogastrid earthworms revealed by mitochondrial and nuclear data. Molecular Phylogenetics and Evolution, 56, 507-512. https://doi.org/10.1016/j.ympev.2010.04.010

Omodeo, P. (1956) Contributo alla revisione dei Lumbricidae. Archivio Zoologico Italiano, 41, 129-212.

Omodeo, P. \& Rota, E. (1989) Earthworms of Turkey. Italian Journal of Zoology, 56, 167-198. https://doi.org/10.1080/11250009109355749

Pérez-Losada, M., Ricoy, M., Marshall, J.C. \& Domínguez, J. (2009) Phylogenetic assessment of the earthworm Aporrectodea caliginosa species complex (Oligochaeta: Lumbricidae) based on mitochondrial and nuclear DNA sequences. Molecular Phylogenetics and Evolution, 52, 293-302.

https://doi.org/10.1016/j.ympev.2009.04.003

Pop, V. (1941) Zur phylogenie und systematik der lumbriciden. Zoologische Jahrbücher Abteilung für Systematik Ökologie und Geographie der Tiere, 74, 487-522.

R Core Team (2021) R: A language and environment for statistical computing. R Foundation for Statistical Computing, Vienna. [program]

Reynolds, J.W. (1977) The earthworms (Lumbricidae and Sparganophilidae) of Ontario. Royal Ontario Museum, Ontario, 141 pp.

Reynolds, J.W. (2017a) Earthworms (Oligochaeta: Acanthodrilidae, Glossoscolecidae, Komarekionidae, Lumbricidae, Megascolecidae, Ocnerodrilidae and Sparganophilidae) in the Piedmont ecoregion, USA. Megadrilogica, 22, 87-96.

Reynolds, J.W. (2017b) Earthworms (Oligochaeta: Acanthodrilidae, Komarekionidae, Lumbricidae, Megascolecidae and Sparganophilidae) in the Central Appalachians Ecoregion, USA. Megadrilogica, 22, 52-60.

Smith, F. (1917) North American earthworms of the family Lumbricidae in the collections of the United States National Museum. Proceedings of the United States National Museum, 52, 157-182.

Smith, F. \& Gittins, E.M. (1915) Two new species of Lumbricidae from Illinois. Bulletin of the Illinois State Laboratory of Natural History, 10, 545-550.

Tripp, E.A., Lendemer, J.C. \& McCain, C.M. (2019) Habitat quality and disturbance drive lichen species richness in a temperate biodiversity hotspot. Oecologia, 190, 445-457. https://doi.org/10.1007/s00442-019-04413-0

Wallace, I.M., O’Sullivan, O., Higgins, D.G. \& Notredame, C. (2006) M-Coffee: Combining multiple sequence alignment methods with T-Coffee. Nucleic Acids Research, 34, 1692-1699. https://doi.org/10.1093/nar/gk1091

Yu, G., Smith, D.K., Zhu, H., Guan, Y. \& Lam, T.T. (2017) ggtree: an R package for visualization and annotation of phylogenetic trees with their covariates and other associated data. Methods in Ecology and Evolution, 8, 28-36. https://doi.org/10.1111/2041-210X.12628

Zicsi, A. (1981) Probleme der Lumbriciden-Systematik sowie die Revision zweier Gattungen (Oligochaeta). Acta Zoologica Hungarica, 27, 431-442. 